\title{
Skrining Isolat Bakteri Asam Laktat Penghasil Bakteriosin yang Diisolasi dari Asinan Rebung Bambu Tabah dan Ketahanannya terhadap Panas Screening for Bacteriocin-Producing Lactic Acid Bacteria Isolated from Pickled of Tabah Bamboo Shoots and the Resistance of Heat
}

I Gede Arya Sujana, Nyoman Semadi Antara*, Ida Bagus Wayan Gunam

PS Teknologi Industri Pertanian, Fakultas Teknologi Pertanian, Universitas Udayana, Kampus Bukit Jimbaran, Badung, Kode pos : 80361; Telp/Fax : (0361) 701801

Diterima 28 September 2020 / Disetujui 19 Nopember 2020

\begin{abstract}
The aim of this study to determine the Lactic Acid Bacteria (LAB) isolated from pickled tabah bamboo shoots can produce bacteriocins and the resistance to heat. This research was conducted in two stages, namely: 1) Screening of $L A B$ isolates producing bacteriocin and 2) Testing the effect of heating temperatures of $80^{\circ} \mathrm{C}$, $100^{\circ} \mathrm{C}$ and $121^{\circ} \mathrm{C}$ for 5,10 and 15 minutes and without heating to bacteriocin resistance activity. In this study, the screening stage was carried out in two stages, namely: 1) antibacterial test with cell free supernatant and 2) antibacterial test with neutralized cell free supernatant. The resulting clear zone is observed then followed by calculating the value of Arbitrary Units (AU). The bacteria used as an indicator is Lactobacillus plantarum which is Gram positive bacteria. The results of this study indicated that of 88 LAB isolates there were 27 isolates that were able to produce bacteriocin. From 27 isolates, there were three isolates with the most potential to produce bacteriocins, namely isolate PR.6.10.5 with an inhibition zone of $17.67 \mathrm{~mm}$ and a bacteriocin activity value of $264.81 \mathrm{~mm}^{2} / \mathrm{ml}$, isolate PR.6.15.2 with an inhibition zone of $17.33 \mathrm{~mm}$ and the bacteriocin activity value of $259.57 \mathrm{~mm}^{2} / \mathrm{ml}$ and isolate PR.3.15.1 with an inhibition zone of $17.00 \mathrm{~mm}$ and a bacteriocin activity value of $254.34 \mathrm{~mm}^{2} / \mathrm{ml}$. Bacteriocins from LAB isolates isolated from pickled tabah bamboo shoots were able to withstand heating to a temperature of $121^{\circ} \mathrm{C}$ for 15 minutes. Bacteriocin activity decreased by an average of $27.75 \%$ after heating at $80^{\circ} \mathrm{C}, 100^{\circ} \mathrm{C}$ and $121^{\circ} \mathrm{C}$ for 5,10 and 15 minutes with a bacteriocin activity value from $141.82 \mathrm{~mm}^{2} / \mathrm{ml}$ to $254.34 \mathrm{~mm}^{2} / \mathrm{ml}$. The smallest decrease in activity value occurred in PR.6.10.5 isolates with an average decrease of $22.98 \%$.
\end{abstract}

Keywords: Screening, lactic acid bacteria (LAB), bacteriocin, heat.

\begin{abstract}
ABSTRAK
Penelitian ini bertujuan untuk mengetahui Bakteri Asam Laktat (BAL) yang diisolasi dari asinan rebung bambu tabah dapat memproduksi bakteriosin dan pengaruh suhu pemanasan terhadap ketahanannya. Penelitian ini dilakukan dalam dua tahap yaitu: 1) Skrining isolat BAL penghasil bakteriosin dan 2) Pengujian pengaruh suhu pemanasan $80^{\circ} \mathrm{C}, 100^{\circ} \mathrm{C}$ dan $121^{\circ} \mathrm{C}$ selama 5,10 dan 15 menit serta tanpa pemanasan terhadap aktivitas ketahanan bakteriosin. Dalam penelitian ini, tahap skrining dilakukan dengan dua tahapan yaitu: 1) Uji antibakteri dengan cell free Supernatant dan 2) Uji antibakteri dengan neutralized cell free supernatant. Zona bening yang dihasilkan diamati kemudian dilanjutkan dengan penghitungan nilai Arbitrary Units (AU).
\end{abstract}

\footnotetext{
*Korespondensi Penulis:

Email: semadi.antara@unud.ac.id
} 
Bakteri yang digunakan sebagai indikator adalah Lactobacillus plantarum yang merupakan bakteri Gram positif. Hasil penelitian ini menunjukkan bahwa dari 88 isolat BAL terdapat 27 isolat yang mampu menghasilkan bakteriosin. Dari 27 isolat, terdapat tiga isolat yang paling berpotensi menghasilkan bakteriosin, yaitu isolat PR.6.10.5 dengan zona hambat $17,67 \mathrm{~mm}$ dan nilai aktivitas bakteriosin $264,81 \mathrm{~mm}^{2} / \mathrm{ml}$, isolat PR.6.15.2 dengan zona hambat $17,33 \mathrm{~mm}$ dan nilai aktivitas bakteriosin $259,57 \mathrm{~mm}^{2} / \mathrm{ml}$ dan isolat PR.3.15.1 dengan zona hambat $17,00 \mathrm{~mm}$ dan nilai aktivitas bakteriosin $254,34 \mathrm{~mm}^{2} / \mathrm{ml}$. Bakteriosin asal isolat BAL yang diisolasi dari asinan rebung bambu tabah mampu bertahan terhadap perlakukan pemanasan hingga pada suhu $121^{\circ} \mathrm{C}$ selama 15 menit. Aktivitas bakteriosin terjadi penurunan rata-rata sebesar $27,75 \%$ setelah dilakukan pemanasan pada suhu $80^{\circ} \mathrm{C}, 100^{\circ} \mathrm{C}$ dan $121^{\circ} \mathrm{C}$ selama 5,10 dan 15 menit dengan nilai aktivitas bakteriosin dari $141,82 \mathrm{~mm}^{2} / \mathrm{ml}$ sampai $254,34 \mathrm{~mm}^{2} / \mathrm{ml}$. Penurunan nilai aktivitas terkecil terjadi pada isolat PR.6.10.5 dengan rata-rata peurunan sebesar 22,98\%.

Kata kunci: Skrining, bakteri asam laktat (BAL), bakteriosin, panas.

\section{PENDAHULUAN}

Asinan rebung bambu tabah merupakan salah satu jenis produk pangan dan sumber bakteri asam laktat (BAL). Asinan rebung bambu tabah memiliki kelebihan sebagai sumber bakteri asam laktat karena adanya penambahan garam dalam proses fermentasinya (Vaughn, 1982). Dalam proses fermentasi, garam berperan sebagai medium selektif bagi BAL dan dapat mempercepat pertumbuhan BAL. Bakteri asam laktat dominan ditemukan pada proses fermentasi asam laktat. Bakteri asam laktat yang melalui fermentasi dapat menghasilkan asam laktat, sejumlah kecil asam asetat dan $\mathrm{pH}$ yang lebih rendah. Fermentasi juga menurunkan kandungan hidro sianida (Darmayanti et al., 2014).

Bakteri asam laktat merupakan golongan bakteri yang aman ditambahkan pada makanan dan dikenal dengan sebutan food grade microorganism yaitu mikroorganisme yang tidak beresiko terhadap kesehatan (Alakomi et al., 2000). Pada industri pengolahan pangan, BAL telah digunakan sebagai kultur starter untuk berbagai ragam fermentasi daging, susu dan sayur-sayuran. Peranan BAL adalah untuk memperbaiki citarasa produk fermentasi dan juga mempunyai efek pengawetan (Kencana et al., 2012).
Bakteri yang tergolong BAL mempunyai aktivitas mikrobial yang tinggi karena metabolit yang dihasilkannya (Adriani et al., 2008; Situmeang et al., 2017). Metabolit BAL dapat merusak permiabilitas membran sel dan akan berakhir dengan bocornya/rusaknya dinding sel mikroorganisme sehingga pertumbuhan sel mikroba terhambat dan akhirnya mengalami kematian (Situmeang et al., 2017). Selain itu BAL juga menghasilkan senyawa-senyawa penghambat lain seperti hidrogen peroksida, diasetil, karbondioksida, reuterin dan bakteriosin (Vuyst dan Vandamme, 1994).

Bakteriosin didefinisikan sebagai senyawa antimikrobia yang disintesis oleh berbagai spesies bakteri termasuk kelompok BAL di dalam ribosom. Bakteriosin merupakan senyawa protein yang mempelihatkan aktivitas antibakteri (bakterisida ataupun bakteriostatik) terhadap spesies bakteri yang bersifat sensitif. Protein yang terdapat dalam bakteriosin seringkali aktif melawan spesies lain yang memiliki hubungan kekerabatan yang dekat dengan bakteri penghasil (Galvez et al., 2007).

Beberapa BAL memproduksi bakteriosin dengan spektrum penghambatan luas.Beberapa bakteriosin juga berpotensi sebagai pengawet pangan. Penggunaan bakteriosin pada industri pangan dapat membantu mengurangi penggunaan bahan pengawet kimiawi ataupun perlakuan panas yang intensif. Dalam hal ini penggunaan 
bakteriosin secara alami akan memberikan nutrisi dan sifat organoleptik yang lebih baik (Galvez et al., 2007). Selain itu bakteriosin dikatakan sangat menarik karena bahan tambahan pangan yang aman dan tidak toksis digunakan sebagai pengawet pangan dan bakteriosin mampu mencegah kerusakan pangan oleh bakteri patogen yang berifat Gram-positif (Hata et al., 2010).

Ketahanan bakteriosin terhadap pemanasan mengindikasikan bahwa bakteriosin tersebut dapat digunakan sebagai preservasi bahan pangan yang dikombinasikan dengan pengolahan menggunakan suhu tinggi untuk produk makanan (Gonzales et al., 1994). Suhu yang digunakan dalam pengolahan makanan ada tiga macam, yakni suhu pasteurisasi dimana digunakan suhu sedang atau moderat berkisar $58 \quad-80^{\circ} \mathrm{C}$ untuk memusnahkan mikroorganisme patogen dan juga pembusuk, suhu perebusan berkisar $100^{\circ} \mathrm{C}$, dan suhu sterilisasi yaitu pemanasan dengan suhu tinggi diatas $100^{\circ} \mathrm{C}$ untuk membunuh semua mikroorganisme pembusuk. Pada umumunya dalam tahap pemanasan, lama waktu yang digunakan berkisar dari 5 - 30 menit.

Bakteri penghasil bakteriosin dapat diisolasi dari produk daging terfermentasi asal Turki (Con dan Goè, 2000), produk daging terfermentasi asal Brazilia, Brazil (Martinis dan Freitas, 2003), produk fermentasi bubur asal Burkina Faso (Omar et al., 2006), produk daging fermentasi tradisional China (Liu et al., 2008), sosis kering (Castro et al., 2011), produk fermentasi daging kering asal Brazil (Biscola et al., 2013) dan pasta udang asal Thailand (Kaewkloma et al., 2013). Bakteriosin juga dapat dihasilkan dari minuman Ce Hun Tiau (Sari et al., 2016) dan fermentasi kakao (Urnemi et al., 2011).

Berdasarkan penelitian sebelumnya yang berjudul studi viabilitas isolat bakteri asam laktat yang diisolasi dari asinan rebung bambu tabah terhadap $\mathrm{pH}$ rendah dan garam empedu oleh Wasis et al. (2018), maka pada penelitian ini bertujuan untuk mengetahui BAL yang diisolasi dari asinan rebung bambu tabah dapat memproduksi bakteriosin. Serta bertujuan untuk mengetahui pengaruh suhu dan lama pemanasan terhadap aktivitas bakteriosin. Adapun suhu uji yang digunakan antara lain: $80^{\circ} \mathrm{C}, 100^{\circ} \mathrm{C}$ dan $121^{\circ} \mathrm{C}$ serta tanpa dilakukan pemanasan, lama waktu yang digunakan untuk pemanasan yaitu 5 menit, 10 menit dan 15 menit.

\section{METODE PENELITIAN}

\section{Tempat dan Waktu}

Penelitian ini dilakukan di Laboratorium Biondustri dan Lingkungan serta Laboratorium Mikrobiologi Pangan, Fakultas Teknologi Pertanian, Universitas Udayana. Waktu pelaksanaan dilakukan pada bulan Februari hingga Maret 2020 serta pada bulan Juli 2020.

\section{Bahan dan Alat Penelitian}

Kultur bakteri yang digunakan adalah isolat bakteri asam laktat hasil isolasi dari asinan rebung bambu tabah dan Lactobacillus plantarum yang diambil dari Laboratorium Bioindustri dan Lingkungan, Universitas Udayana yang disimpan dalam stock gliserol. Media yang digunakan antara lain De Man Ragosa Sharpe Broth (MRS Broth), De Man Ragosa Sharpe Agar (MRSA), spritus, alkohol, $\mathrm{NaOH} 1 \mathrm{~N}$ dan aquadest.

Peralatan yang digunakan pada penelitian ini adalah tabung reaksi (PirexIwaki), cawan petri (Pirex-Iwaki), gelas beker (Pirex-Iwaki), pipet tetes kaca dan gelas ukur, autoclave (Daihan Sceintific), water bath (Wina Instruments), inkubator (Memmert), water bath shaker (Wina Instruments), mikro pipet, timbangan digital (Camry), laminar air flow (Wina Airflow), magnetic sirrer (Ika C-MAG HS 7), vortex (Thermo Sceintific), sentrifuge (UniCen MRHerolab $\mathrm{GmbH}$ ), spatula, batang pengaduk, batang bengkok, penjepit, alumunium foil, 
jangka sorong, rak tabung reaksi, kulkas/freezer, gunting, plastik anti panas, tisu, kertas label, detergen, karet, kapas, serta alat dokumentasi.

\section{Tahapan Penelitian}

Penelitian ini bersifat eksplorasi yang dilakukan dalam 2 tahapan yaitu:

1. Skrining atau penentuan isolat BAL yang menghasilkan bakteriosin dan

2. Pegujian pengaruh suhu pemanasan terhadap aktivitas ketahanan bakteriosin.

Adapun dalam penelitian ini, isolat BAL yang digunakan sebanyak 88 isolat hasil isolasi dari asinan rebung bambu tabah untuk pengujian aktivitas bakteriosin.

\section{Pelaksanaan Percobaan \\ Pembuatan Media MRS Broth dan MRS Agar}

Pembuatan dimulai dengan menimbang sebanyak 26,1 gram MRS Broth dimasukkan ke dalam gelas beker, dilarutkan dengan akuades hingga volume $500 \mathrm{ml}$. Media MRSA dibuat dengan cara melarutkan MRSA bubuk sebanyak 34, 1 gram dalam 500 $\mathrm{ml}$ aquades. Selanjutnya dimasukkan ke dalam autoclave untuk disterilisasi pada suhu $121^{\circ} \mathrm{C}$ tekanan 1 atm dan dibiarkan selama 15 menit. Media siap digunakan untuk perbanyakan bakteri.

\section{Perbanyakan Bakteri Asam Laktat}

Perbanyakan bakteri asam laktat dilakukan dengan menginokulasikan 88 isolat BAL masing - masing sebanyak $100 \mu 1$ ke dalam tabung reaksi yang berisi $5 \mathrm{ml}$ MRS Broth. Selanjutnya diinkubasi pada incubator shaker dengan kecepatan $120 \mathrm{rpm}$ dan suhu $37^{\circ} \mathrm{C}$ selama 24 jam sehingga diperoleh kultur aktif yaitu perubahan media menjadi keruh. Kultur aktif ini siap digunakan untuk pengujian antibakteri bakteriosin.

\section{Perbanyakan Bakteri Lactobacillus plantarum sebagai Bakteri Indikator Perbanyakan bakteri indikator dilakukan dengan menginokulasi isolat}

Lactobacillus plantarum sebanyak $100 \mu \mathrm{lke}$ dalam tabung reaksi yang berisi $5 \mathrm{ml}$ MRS Broth. Selanjutnya diinkubasi pada incubator shaker dengan kecepatan $120 \mathrm{rpm}$ dan suhu $37^{\circ} \mathrm{C}$ selama 24 jam sehingga diperoleh kultur aktif yaitu ditandai adanya perubahan media menjadi keruh yang menandakan adanya pertumbuhan bakteri. Kultur aktif ini siap digunakan untuk pengujian.

\section{Skrining Bakteriosin \\ Uji Antibakteri dengan Cell Free Supernatant}

Dalam tahapan ini dilakukan penyeleksian isolat BAL untuk memperoleh BAL yang positif mengandung bakteriosin. Isolat BAL yang telah diinokulasi selanjutnya dilakukan pemisahan endapan selnya dengan disentrifugasi pada $8.500 \mathrm{rpm}, 4^{\circ} \mathrm{C}$ selama 25 menit (Harianie, 2013). Sebelum disentrifugasi terlebih dahulu dilakukan tahap head treatment selama 5 menit, tahapan ini dilakukan untuk menghentikan pertumbuhan enzim. Proses sentrifugasi dilakukan untuk mendapatkan supernatan antibakteri.

Selanjutnya dilakukan uji antibakteri untuk mengetahui kemampuan isolat bakteri asam laktat dalam menghambat pertumbuhan bakteri uji atau indikator, menggunakan metode sumur yang mengacu pada Poelongan et al. (2006) dan NCCLS. Media MRSA yang telah disterilkan dimasukkan ke dalam cawan petri masing-masing sebanyak $20 \mathrm{ml}$ hingga memadat. Media tersebut diinokulasi dengan $100 \mu \mathrm{l}$ suspensi bakteri indikator dengan metode sebar dan diratakan mengunakan batang bengkok selanjutnya didiamkan hingga kering. Setelah itu dibuat lubang (sumuran) dengan menggunakan ujung pipet steril dan lubang sumuran dilapisi agar steril. Sebanyak $50 \mu \mathrm{l}$ isolat bakteri asam laktat supernatan bebas sel dimasukkan ke dalam sumuran yang telah disediakan. Selanjutnya diinkubasi pada suhu $37^{\circ} \mathrm{C}$ selama 24 jam (Usmiati dan Marwati, 2007). Aktivitas antimikroba ditunjukkan dengan adanya zona 
bening disekitar sumuran. Zona bening yang terbentuk diukur diameternya sebanyak tiga kali menggunakan jangka sorong pada posisi yang berbeda dan dirata-ratakan.

\section{Uji Antibakteri dengan Neutralized Cell Free Supernatant}

Setelah dilakukan uji antibakteri dengan cell free supernatant terhadap bakteri indikator selanjutnya dilakukan tahapan uji antibakteri lanjutan dengan neutralized cell free supernatant. Setelah dilakukan uji antibakteri awal yang ditandai dengan adanya zona bening, selanjutnya dipilih isolat BAL yang memiliki zona bening $\geq 1 \mathrm{~mm}$ untuk uji antibakteri lanjutan pada neutralized cell free supernatant. Setelah diperoleh isolat BAL supernatan, selanjutnya filtrat dilakukan penetralan $\mathrm{pH}$ hingga $\mathrm{pH} 6,8$ dengan $\mathrm{NaOH}$ 1N (Harianie, 2013).

Setelah diperoleh filtrat Isolat BAL yang telah dinetralkan, selanjutnya dilakukan uji antibakteri bakteriosin untuk mengetahui kemampuan isolat bakteri asam laktat dalam menghambat pertumbuhan bakteri uji atau indikator, menggunakan metode sumur yang mengacu pada Poelongan et al. (2006) dan NCCLS. Media MRSA yang telah disterilkan dimasukkan ke dalam cawan petri masingmasing sebanyak $20 \mathrm{ml}$ hingga memadat. Media tersebut diinokulasi dengan $100 \mu \mathrm{l}$ bakteri indikator dan diratakan mengunakan batang bengkok dan didiamkan hingga kering. Selanjutnya dibuat lubang (sumuran) dengan menggunakan ujung pipet steril dan lubang sumuran dilapisi agar steril. Sebanyak $50 \mu 1$ netral supernatan bebas sel diteteskan ke dalam sumuran yang telah disediakan. Selanjutnya diinkubasi pada suhu $37^{\circ} \mathrm{C}$ selama 24 jam (Usmiati dan Marwati, 2007). Aktivitas bakteriosin ditunjukkan dengan adanya zona bening disekitar sumuran.

Aktivitas bakteriosin dinyatakan dengan Arbitrary Units per $\mathrm{ml}$ (AU/ml). Arbitrary Units adalah unit relatif pengukuran untuk menunjukkan rasio jumlah zat, intensitas, atau jumlah lainnya ke pengukuran referensi yang telah ditentukan (Olesen, 1995). Satu AU/ml merupakan luas daerah hambat per satuan volume sampel bakteriosin uji $\left(\mathrm{mm}^{2} / \mathrm{ml}\right)$ (Usmiati dan Marwati, 2007).

Secara matematis aktivitas bakteriosin dapat dihitung dengan menggunakan persamaan luas daerah hambat per satuan volume sampel bakteriosin uji. Persamaan matematis dapat digambarakan sebagai berikut:

Aktivitas bakteriosin $\left(\mathrm{mm}^{2} / \mathrm{ml}\right)=\frac{L z-L S}{V}$

Dimana:

$$
\begin{array}{ll}
\mathrm{Lz} & =\text { Luas zona bening }\left(\mathrm{mm}^{2}\right) \mathrm{Ls}=\text { Luas } \\
\mathrm{V} & \text { sumur }\left(\mathrm{mm}^{2}\right) \\
& =\text { Volume sampel }(\mathrm{ml})
\end{array}
$$

\section{Uji Ketahanan Bakteriosin terhadap} Panas

Bakteriosin diuji ketahanannya terhadap empat suhu pemanasan yang merupakan modifikasi dari penelitian AboAmer (2007) dan Ivanova et al (2000) yaitu:

1) Suhu ruang/tanpa pemanasan serta tanpa penggunaan waktu.

2) Suhu pasteurisasi, yakni pemanasan dengan suhu $80^{\circ} \mathrm{C}$ selama 5 menit, 10 menit dan 15 menit.

3) Suhu $100^{\circ} \mathrm{C}$ sebagai representasi suhu titik didih air selama 5 menit, 10 menit dan 15 menit.

4) Suhu sterilisasi, yakni pemanasan dengan suhu $121^{\circ} \mathrm{C}$ selama 5 menit, 10 menit dan 15 menit.

\section{HASIL DAN PEMBAHASAN}

\section{Skrining Bakteriosin}

Dari 88 isolat BAL yang diisolasi dari asinan rebung bambu tabah (Wasis et al.,2019) diperoleh sebanyak 27 isolat yang dinyatakan positif menghasilkan bakteriosin. Dari 27 isolat tersebut terdapat 3 isolat yang berpotensial untuk menghasilkan bakteriosin.

Suatu isolat dapat dikatakan berpotensial karena 3 isolat tersebut memiliki 
nilai aktivitas bakteriosin atau AU tertinggi, dalam hasil penelitian ini terdapat 3 isolat yang memiliki nilai $\mathrm{AU} \geq 250 \mathrm{~mm}^{2} / \mathrm{ml}$. Selain itu juga memiliki diameter zona hambat yang tinggi atau $\geq 6 \mathrm{~mm}$ apabila telah dikurangi dengan diameter sumuran (Pan.,
2009). Suatu isolat BAL dapat dikatakan mampu menghasilkan bakteriosin apabila memiliki zona hambat atau zona bening $\geq 1$ mm (Harianie, 2013). Isolat yang berpotensial menghasilkan bakteriosin disajikan pada Tabel 1.

Tabel 1. Isolat yang berpotensi menghasilkan bakteriosin

\begin{tabular}{|c|c|c|c|c|c|c|c|c|c|}
\hline \multirow[t]{2}{*}{ NO } & \multirow[t]{2}{*}{ Kode Isolat } & \multicolumn{3}{|c|}{$\begin{array}{l}\text { Perhitungan Zona } \\
\text { Bening (mm) }\end{array}$} & \multirow{2}{*}{$\begin{array}{l}\text { Rata-Rata } \\
\quad(\mathbf{m m})\end{array}$} & \multirow{2}{*}{$\begin{array}{c}\text { Luas Zona } \\
\text { Bening (Lz) } \\
(\mathbf{m m 2})\end{array}$} & \multirow{2}{*}{$\begin{array}{c}\text { Luas } \\
\text { Sumuran } \\
(\mathbf{L s})(\mathbf{m m 2})\end{array}$} & \multirow{2}{*}{$\begin{array}{l}\text { Volume } \\
\text { sampel } \\
\text { (v) (ml) }\end{array}$} & \multirow{2}{*}{$\begin{array}{c}\text { Nilai Aktivitas } \\
\text { Bakteriosin (AU) } \\
(\mathrm{mm} 2 / \mathrm{ml})\end{array}$} \\
\hline & & I & II & III & & & & & \\
\hline 1 & PR.6.10.5 & 18 & 18 & 17 & 17.67 & 13.87 & 0.63 & 0.05 & 264.81 \\
\hline 2 & PR.6.15.2 & 17 & 17 & 18 & 17.33 & 13.61 & 0.63 & 0.05 & 259.57 \\
\hline 3 & PR.3.15.1 & 16 & 18 & 17 & 17.00 & 13.35 & 0.63 & 0.05 & 254.34 \\
\hline 4 & PR.3.10.3 & 15 & 18 & 16 & 16.33 & 12.82 & 0.63 & 0.05 & 243.87 \\
\hline 5 & PR.9.5.3 & 15 & 18 & 16 & 16.33 & 12.82 & 0.63 & 0.05 & 243.87 \\
\hline 6 & PR.9.10.8 & 18 & 15 & 16 & 16.33 & 12.82 & 0.63 & 0.05 & 243.87 \\
\hline 7 & PR.6.5.9 & 17 & 14 & 15 & 15.33 & 12.04 & 0.63 & 0.05 & 228.17 \\
\hline 8 & PR.9.10.9 & 16 & 14 & 15 & 15.00 & 11.78 & 0.63 & 0.05 & 222.94 \\
\hline 9 & PR.9.15.4 & 14 & 16 & 15 & 15.00 & 11.78 & 0.63 & 0.05 & 222.94 \\
\hline 10 & PR.3.10.8 & 14 & 15 & 15 & 14.67 & 11.51 & 0.63 & 0.05 & 217.71 \\
\hline 11 & PR.9.5.10 & 15 & 12 & 16 & 14.33 & 11.25 & 0.63 & 0.05 & 212.47 \\
\hline 12 & PR.3.5.4 & 14 & 14 & 14 & 14.00 & 10.99 & 0.63 & 0.05 & 207.24 \\
\hline 13 & PR.9.15.5 & 14 & 13 & 14 & 13.67 & 10.73 & 0.63 & 0.05 & 202.01 \\
\hline 14 & PR.9.15.7 & 14 & 13 & 14 & 13.67 & 10.73 & 0.63 & 0.05 & 202.01 \\
\hline 15 & PR.9.5.9 & 14 & 13 & 14 & 13.67 & 10.73 & 0.63 & 0.05 & 202.01 \\
\hline 16 & PR.6.10.3 & 12 & 15 & 13 & 13.33 & 10.47 & 0.63 & 0.05 & 196.77 \\
\hline 17 & PR.6.15.3 & 11 & 14 & 14 & 13.00 & 10.21 & 0.63 & 0.05 & 191.54 \\
\hline 18 & PR.6.5.3 & 12 & 12 & 12 & 12.00 & 9.42 & 0.63 & 0.05 & 175.84 \\
\hline 19 & PR.9.15.10 & 12 & 12 & 12 & 12.00 & 9.42 & 0.63 & 0.05 & 175.84 \\
\hline 20 & PR.6.15.10 & 12 & 11 & 12 & 11.67 & 9.16 & 0.63 & 0.05 & 170.61 \\
\hline 21 & PR.6.15.1 & 12 & 11 & 12 & 11.67 & 9.16 & 0.63 & 0.05 & 170.61 \\
\hline 22 & PR.3.15.8 & 11 & 12 & 12 & 11.67 & 9.16 & 0.63 & 0.05 & 170.61 \\
\hline 23 & PR.3.10.10 & 11 & 12 & 11 & 11.33 & 8.90 & 0.63 & 0.05 & 165.37 \\
\hline 24 & PR.9.15.9 & 11 & 10 & 12 & 11.00 & 8.64 & 0.63 & 0.05 & 160.14 \\
\hline 25 & PR.3.15.10 & 11 & 10 & 12 & 11.00 & 8.64 & 0.63 & 0.05 & 160.14 \\
\hline 26 & PR.6.10.7 & 11 & 10 & 11 & 10.67 & 8.37 & 0.63 & 0.05 & 154.91 \\
\hline 27 & PR.3.15.6 & 10 & 11 & 11 & 10.67 & 8.37 & 0.63 & 0.05 & 154.91 \\
\hline
\end{tabular}

Berdasarkan data pada Tabel 1, diketahui bahwa diameter zona hambat supernatan netral terhadap bakteri Lactobacillus plantarum sebesar 17,67 mm (isolat PR.6.10.5) dengan nilai aktivitas bakteriosin sebesar $264,81 \mathrm{~mm}^{2} / \mathrm{ml}, 17,33$ $\mathrm{mm}$ (isolat PR.6.15.2) dengan nilai aktivitas bakteriosin sebesar $259,57 \mathrm{~mm}^{2} / \mathrm{ml}$ dan 17,00 $\mathrm{mm}$ (isolat PR.3.15.1) dengan nilai aktivitas bakteriosin sebesar 254,34 $\mathrm{mm}^{2} / \mathrm{ml}$. Supernatan yang telah dinetralkan menyebabkan hilangnya pengaruh asam organik yang terkandung dalam supernatan sehingga aktivitas antimikroba yang dihasilkan supernatan netral tidak akan sebesar aktivitas antimikroba supernatan bebas sel (Pan et al., 2009).

Pan et al., (2009) menyatakan bahwa kekuatan aktivitas antimikroba dikategorikan pada ukuran diameter zona hambat: diameter zona hambat sama dengan diameter sumur berarti tidak ada penghambatan, diameter diantara 1-3 $\mathrm{mm}$ berarti penghambatan lemah, diameter diantara 3-6 $\mathrm{mm}$ berarti penghambatan sedang dan diameter $>6 \mathrm{~mm}$ berarti aktivitas penghambatan kuat. Untuk lebih jelasnya zona hambat yang dihasilkan dari ketiga isolat yang berpotensial sebagai bakteriosin dapat dilihat pada Gambar 1 . 


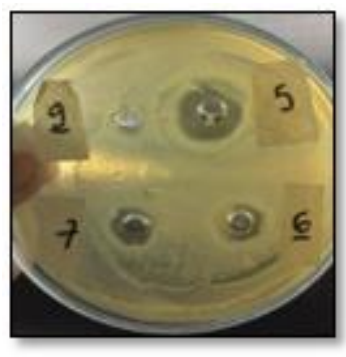

(a)

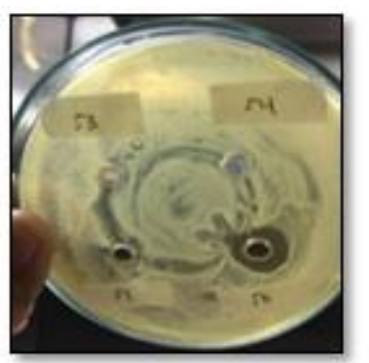

(b)

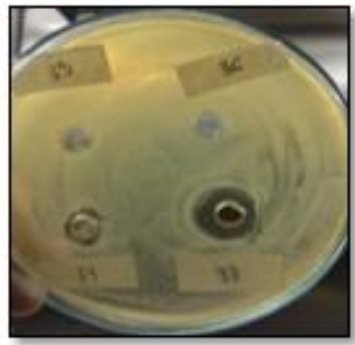

(c)

Gambar 1. Zona bening: (a) isolat PR.6.10.5 (kode 5), (b) isolat PR.6.15.2 (kode 50) dan (c) isolat PR.3.15.1 (kode 33).

\section{Uji Ketahanan Bakteriosin terhadap Panas}

Isolat BAL yang digunakan pada penelitian ini adalah isolat yang potensial menghasilkan bakteriosin dari hasil pengujian sebelumnya, adapun isolat yang digunakan antara lain: PR.6.10.5, PR.6.15.2 dan isolat PR.3.15.1. Dari hasil penelitian ini diperoleh bahwa ketiga isolat BAL tersebut mampu menghasilkan bakteriosin yang tahan terhadap panas. Bakteriosin yang dihasilkan tahan terhadap pemanasan pada suhu $80^{\circ} \mathrm{C}$, $100^{\circ} \mathrm{C}$ dan $121^{\circ} \mathrm{C}$ selama 5,10 dan 15 menit. Hasil pengamatan dapat dilihat pada Gambar 2.

Hasil nilai AU yang diperoleh dari pengujian aktivitas bakteriosin terhadap pengaruh suhu pemanasan terhadap bakteri indikator Lactobacillus plantarum adalah sebesar 154,91 $\mathrm{mm}^{2} / \mathrm{ml}$ sampai 212,47 $\mathrm{mm}^{2} / \mathrm{ml}$ pada suhu $80^{\circ} \mathrm{C}$ (selama 5,10 dan 15 menit), $152,29 \mathrm{~mm}^{2} / \mathrm{ml}$ sampai 188,92 $\mathrm{mm}^{2} / \mathrm{ml}$ pada suhu $100^{\circ} \mathrm{C}$ (selama 5,10 dan 15 menit) serta $141,82 \mathrm{~mm}^{2} / \mathrm{ml}$ sampai $186,31 \mathrm{~mm}^{2} / \mathrm{ml}$ pada suhu $121^{\circ} \mathrm{C}$ (selama 5,10 dan 15 menit). Sedangkan tanpa perlakuan panas diperoleh nilai AU sebesar $254,34 \mathrm{~mm}^{2} / \mathrm{ml}$ untuk isolat PR.6.10.5, $236,02 \mathrm{~mm}^{2} / \mathrm{ml}$ untuk isolat PR.6.15.2 dan $230,79 \mathrm{~mm}^{2} / \mathrm{ml}$ untuk isolat PR.3.15.1. Hal tersebut dapat dikatakan bahwa bakteriosin asal isolat BAL yang diisolasi dari asinan rebung bambu tabah mampu bertahan terhadap perlakukan pemanasan atau dapat dikatakan stabil hingga pemanasan pada suhu $121^{\circ} \mathrm{C}$ selama 15 menit. Suwayvia (2017) juga melaporkan bahwa bakteriosin yang dihasilkan L. plantarum FNCC 0020 memiliki sifat stabil terhadap pemanasan hingga suhu $121^{\circ} \mathrm{C}$ selama 15 menit. Sedangkan Villani et al. (2001) melaporkan bahwa aktivitas antimikroba Lactococcus garvieae L-1 benar-benar hilang setelah pemanasan pada suhu $121^{\circ} \mathrm{C}$ selama 15 menit.

Hasil dari penelitin ini juga menunjukkan terjadi penurunan aktivitas bakteriosin pada pengujian ketahanan terhadap panas. Dari hasil penelitian ini dapat diketahui bahwa semakin tinggi suhu dan lama waktu yang digunakan dapat mengurangi aktivitas bakteriosin yang dihasilkan. Hasil dari isolat PR.6.10.5 dengan perlakukan pemanasan pada suhu $80^{\circ} \mathrm{C}$, $100^{\circ} \mathrm{C}$ dan $121^{\circ} \mathrm{C}$ selama 5 menit terjadi penurunan secara berturut-turut sebesar $16,46 \%$ menjadi $212,47 \mathrm{~mm}^{2} / \mathrm{ml}, 25,72 \%$ menjadi $188,92 \mathrm{~mm}^{2} / \mathrm{ml}$ dan $26,75 \%$ menjadi $186,31 \mathrm{~mm}^{2} / \mathrm{ml}$ dari nilai AU tanpa perlakuan panas, sedangkan pada saat pemanasan 10 menit mengalami penurunan nilai aktivitas bakteriosin sebesar $27,78 \%$ dan 15 menit juga mengalami penurunan nilai aktivitas bakteriosin sebesar $33,27 \%$. Sehingga pada isolat PR.6.10.5 mengalami penurunan nilai aktivitas bakteriosin rata-rata sebesar 22,98\%. Untuk isolat PR.6.15.2 dan PR.3.15.1 secara rata-rata juga mengalami 
penurunan nilai aktivitas bakteriosin sebesar $30,67 \%$ dan $29,6 \%$ setelah dipanaskan pada

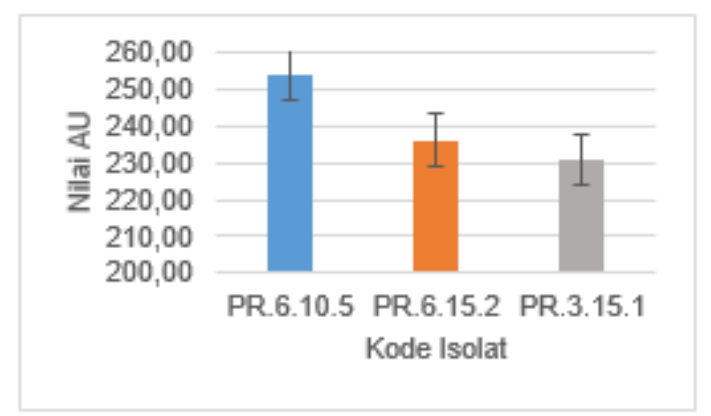

(a)

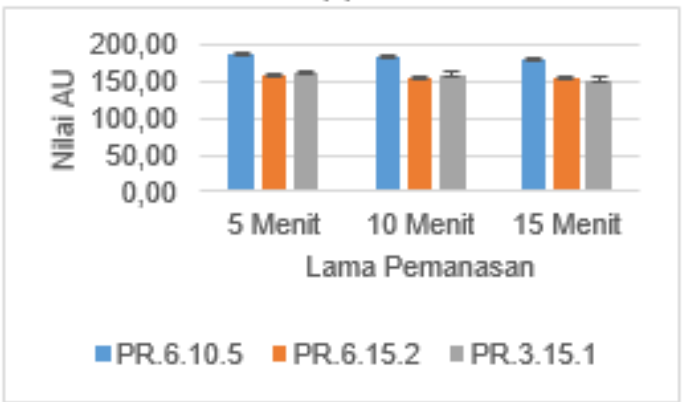

(c) suhu $80^{\circ} \mathrm{C}, 100^{\circ} \mathrm{C}$ dan $121^{\circ} \mathrm{C}$ selama 5,10 dan 15 menit.

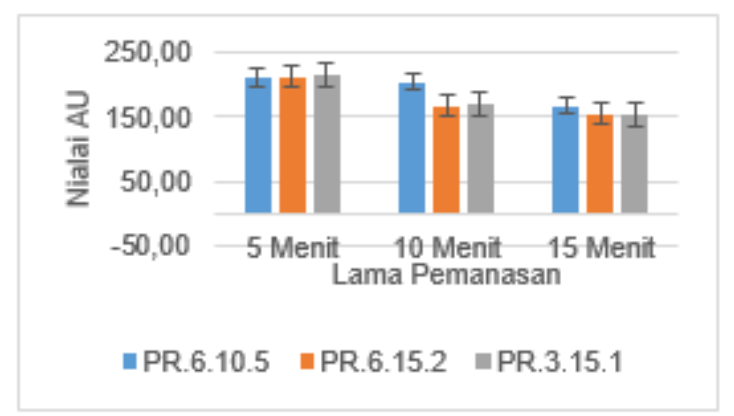

(b)

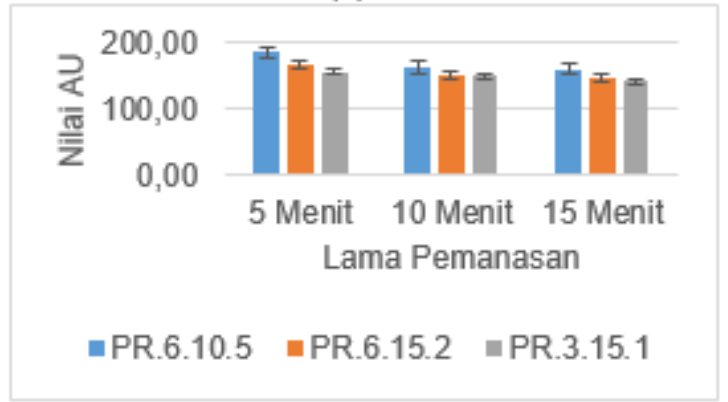

(d)

Gambar 2. Diagram batang dari: (a) Nilai AU pada Perlakukan Tanpa Pemanasan, (b) Nilai AU Dengan Perlakuan Pemanasan $80^{\circ} \mathrm{C}$, (c) Nilai AU dengan perlakuan pemanasan $100^{\circ} \mathrm{C}$ dan (d) Nilai AU dengan perlakuan pemanasan $121^{\circ} \mathrm{C}$.

Nilai aktivitas bakteriosin antara tanpa perlakuan pemanasan dan perlakuan pemanasan juga mengalami perbedaan nilai aktivitas. Setelah dilakukan perlakukan pemanasan nilai aktivitas bakteriosin dari ketiga isolat tersebut mengalami penurunan nilai aktivitas. Secara keseluruhan atau ratatata penurunan nilai aktivitas bakteriosin terjadi sebesar $27,75 \%$ setelah dilakukan pemanasan selama 5,10 dan 15 menit. Kout (2016) menyebutkan bahwa aktivitas antimikroba bakteriosin asal Enterococcus sp. GHB26 hilang sebesar 50\% setelah pemanasan $121^{\circ} \mathrm{C}$, Sankar (2012) melaporkan pula bahwa aktivitas antimikroba L. plantarum hasil isolasi dari susu sapi turun hingga $80 \%$ setelah pemanasan suhu $121^{\circ} \mathrm{C}$.

Perubahan suhu dapat mengurangi aktivitas biokimia protein (Poedjiadi, 2006). Kusmarwati (2014) menjelaskan bahwa masih adanya aktivitas antibakteri oleh bakteriosin ketika diberi perlakuan pemanasan diduga karena bakteriosin merupakan peptida pendek yang stabil terhadap panas. Selain itu, karena adanya asam-asam amino tertentu pada bakteriosin tersebut yang mampu mempertahankan struktur bakteriosin dari pengaruh panas. Najim (2012) menyebutkan bahwa stabilitas terhadap panas dapat dihubungkan dengan formasi struktur globular yang kecil dan menyebabkan kuatnya daerah hidrofobik, kestabilan ikatan silang dan kandungan sistein yang tinggi. Kestabilan terhadap pemanasan ini merupakan suatu keuntungan dan merupakan parameter yang sangat penting jika bakteriosin akan diaplikasikan sebagai pengawet makanan sebab prosedurprosedur pemrosesan makanan banyak melibatkan pemanasan (Vuyst, 1994). Dundar (2006) menyatakan bahwa resistensi terhadap panas merupakan karakteristik 
umum untuk berbagai jenis bakteriosin yang diproduksi oleh BAL.

\section{KESIMPULAN DAN SARAN}

\section{Kesimpulan}

Berdasarkan penelitian yang telah dilakukan maka dapat disimpulkan beberapa hal sebagai berikut:

1. Dari 88 isolat BAL dari asinan rebung bambu tabah diperoleh sebanyak 27 isolat yang mampu menghasilkan bakteriosin. Dari 27 isolat tersebut terdapa 3 isolat yang berpotensial yaitu isolat PR.6.10.5 dengan zona hambat sebesar $17,67 \mathrm{~mm}$ serta nilai aktivitas bakteriosin sebesar $264,81 \mathrm{~mm}^{2} / \mathrm{ml}$, isolate PR.6.15.2 dengan zona hambat sebesar $17,33 \mathrm{~mm}$ serta nilai aktivitas bakteriosin sebesar 259,57 $\mathrm{mm}^{2} / \mathrm{ml}$ dan isolat PR.3.15.1 dengan zona hambat sebesar $17,00 \mathrm{~mm}$ serta nilai aktivitas bakteriosin sebesar 254,34 $\mathrm{mm}^{2} / \mathrm{ml}$.

2. Bakteriosin asal isolat BAL yang diisolasi dari asinan rebung bambu tabah mampu bertahan dengan stabil terhadap perlakukan pemanasan hingga pada suhu $121^{\circ} \mathrm{C}$ selama 15 menit. Aktivitas bakteriosin terjadi penurunan rata-rata sebesar $27,75 \%$ setelah dilakukan pemanasan pada suhu $80^{\circ} \mathrm{C}, 100^{\circ} \mathrm{C}$ dan $121^{\circ} \mathrm{C}$ selama 5,10 dan 15 menit dengan nilai aktivitas bakteriosin dari 141,82 $\mathrm{mm}^{2} / \mathrm{ml}$ sampai $254,34 \quad \mathrm{~mm}^{2} / \mathrm{ml}$. Penurunan nilai aktivitas terkecil terjadi pada isolat PR.6.10.5 dengan rata-rata peurunan sebesar $22,98 \%$.

\section{Saran}

Adapun saran dari hasil penelitian ini adalah sebagai berikut:

1. Perlu dilakukan penelitian lebih lanjut mengenai karakteristik bakteriosin tersebut dengan melakukan pengujian pengaruh suhu dan waktu inkubasi, pengaruh $\mathrm{pH}$, pengaruh suhu dan waktu penyimpanan dan lain-lain.
2. Perlunya dilakukan pengaplikasian bakteriosin tersebut terhadap pengawetan bahan makanan.

\section{DAFTAR PUSTAKA}

Abo, A. and A. Amer. 2007. Characterization of a bacteriocin-like inhibitory substance produced by Lactobacillus plantarum isolated from Egyptian homemade yoghurt. Science Asia journal. 33(2): 313-319.

Adriani, L., N. Indrayati, U. H. Tanuwiria dan N. Mayasari. 2008. Aktivitas Lactobacillus acidophilus dan Bifidobacterium terhadap kualitas yoghurt dan penghambatannya pada Helicobacter pylori. Jurnal Bionatura. 10(2): 129-140.

Alakomi, H.L., E. Skytta, Saarela and S.T. Mattia. 2000. Lactic acid permeabilizes gram-negative bacteria by disrupting the outher membrane. Applied and Environmental Microbiology Journal. 66(5): 2001-2005.

Aryanta, I.W.R. 2013. Mikrobiologi Pangan dan Pakan. Udayana University Press, Denpasar.

Afriani, N., Yusmarini dan U. Pato. 2017. Aktivitas antimikroba Lactobacillus plantarum 1 yang diisolasi dari industri pengolahan pati sagu terhadap bakteri patogen Escherichia coli FNCC-19 dan Staphylococcus aureus FNCC-15. Jurnal JOM PAPERTA. 4(2): 1-12.

Andoko, A. 2003. Budi Daya Bambu Rebung. Kanisius, Yogyakarta.

Biscola, V., S.D. Todorov, V.S.C. Capuano, H. Abriouel, A. Galvez and B.D.G.M. Franco. 2013. Isolation and characterization of a nisin-like bacteriocin produced by a Lactococcus lactis strain isolated from charquia Brazilian fermented, salted and dried 
meat product. Meat Science Journal. 93(3): $607-613$.

Castro, M.P., N.Z. Palavecino, C. Herman, O.A. Garro and C.A. Campos. 2011. Lactic acid bacteria isolated from artisanal dry sausages: characterization of antibacterial compounds and study of the factor saffecting bacteriocin production. Meat Science Journal. 87(4): 321-329.

Con, A.H. and K.H.Y GoÈ. 2000. Production of bacteriocin-like metabolite by lactic acid cultures isolated from sucuk samples. Meat Science Journal. 55(1): 89-96.

Darmayanti, L.P.T., A.A. Duwipayana, I.N.K. Putra and N.S. Antara. 2014. Preliminary study of fermented pickle of tabah bamboo shoot (Gigantochloa nigrociliata Buese Kurz). International Journal of Bioengineering and Life Sciences. 8(10): 1108-1113.

Dundar, H. 2006. Characterization and Purification of A Bacteriocin Produced by Leuconostoc mesenteroides subsp. Cremoris. Thesis. Middle East Technical University, Ankara.

European Food Safety Authority (EFSA). 2012. Guidance on the assessment of bacterial susceptibility to antimicrobials of human and veterinary importance. EFSA Journal. 10 (6): 110.

Fardiaz, S., 1992. Mikrobiologi Pangan I. Gramedia Pustaka Utama, Jakarta.

Food and Agriculture Organization of United Nations \& Organization (FAO). 2002. Guidelines for the Evaluation of Probiotics in Food. Report of a Joint FAO/WHO Working Group on Drafting Guidelines for the Evaluation of Probiotics in Food, London.

Galvez, A. and H. Abriouel. 2007.
Bacteriocin-based strategies for food biopreservation. Food Microbiol journal. 120(1-2): 51-70.

Gonzales, B., P. Arca, B. Mayo and J.E. Suarez. 1994. Detection, purification and partial characterization of plantaricin c, a bacteriocin produced by a Lactobacillus plantarum strain of dairy origin. Journal Application Environment Microbial. 60(6): 21582163.

Harianie, L. 2013. Produksi bakteriosin oleh Lactobacillus plantarum DJ3 dan aplikasinya sebagai pengawet daging. Jurnal El Hayah. 4(1): 1-15.

Hata, T., R. Tanaka and S. Ohmomo. 2010. Isolation and characterization of plantaricin ASM1: a new bacteriocin produced by Lactobacillus plantarum A-1. Food Microbiol Journal. 137(1): 94-99.

Ivanova, I. P., A. Kabadjova. S. Pantev, Danova and X. Dousset. 2000. Detection, purification and partial characterization of a novel bacteriocins substance produced by Lactococcus lactis B14 isolated from BozaBulgarian traditional cereal beverage. Journal of Biocatalyst. 41(6): 47-53.

Kaewkloma, S., S. Lumlert, W. Kraikul and R. Aunpada. 2013. Control of Listeria monocytogenes on sliced bologna sausage using a novel bacteriocin, amysin, produced by Bacillus amyloliquefaciens isolated from Thai shrimp paste (Kapi). Journal of Food Control. 32(2): 552-557.

Kasi, P.D., Ariandi dan H. Mutmainnah. 2017. Uji antibakteri isolat bakteri asam laktat yang diisolasi dari limbah cair sagu terhadap bakteri pantogen. Jurnal Biotropika. 5(3): 97-101.

Kencana P.K.D., W. Widia, dan N.S. Antara. 
2012. Praktek Baik Budi Daya Bambu Rebung Bambu Tabah (Gigantochloa Nigrociliata BUSE - KURZ). Team UNUD - USAID - TPC Project, Universitas Udayana. p 7-13.

Khoiriyah, Hanimatul dan P. Ardiningsih. 2014. Penentuan waktu inkubasi optimum terhadap aktivitas bakteriosin Lactobacillus sp. RED4. Jurnal Kimia Khatulistiwa. 3(4): 52-56.

Kout, Amel, F. Dalache, H.Z. Karam and N.E. Karam. 2016. Characterization and purification of bacteriocin produced by Enterococcus sp. GHB26 from Algerian paste of dates "Ghars". Academic Journal African Journal of Microbiology Reasearch. 10(25): 930937.

Kusmarwati, Arifah, F.R. Arief dan S. Haryati. 2014. Eksplorasi bakteriosin dari bakteri asam laktat asal rusip Bangka dan Kalimantan. JPB Perikanan. 9(1): 29-40.

Liu, G., Y. Lv, P. Li, K. Zhou and J. Zhang. 2008. Pentocin 31-1, an anti-Listeria bacteriocin produced by Lactobacillus pentosus 31-1 isolated from XuanWeiHam, a traditional China fermented meat product. Journal of Food Control. 19(4): 353-359.

Martinis, D.E.C.P. and F.Z. Freitas. 2003. Screening oflactic acid bacteria from Brazilian meats forbacteriocin formation. Journal of Food Control. 14(3): 197-200.

Najim, Hadi, Z.A. Mohammed and Z.S. Khudir. 2012. The Antibacterial Activity of Bacteriocin Produced by Lactobacillus acidophilus Isolates Againts Sensitive Reference Strain Lactobacillus acidophilus R0052 and its Stability to Different $\mathrm{pH}$, Heating and Storage Temperatures. Proceeding of The Eleventh Veterinary Scientific
Conference, University of Baghdad. $\mathrm{p}$ 274-279.

National Committee for Clinical Laboratory Standards (NCCLS). 2005. Manual of Antimicrobial Susceptibility Testing. American Society for Microbiolog, Washington DC.

Olesen, H. 1995. Properties and units in the clinical laboratory sciences i syntax and semantic rules. International Union of Pure and Applied Chemistry (IUPAC). 67(8/9): 1563-1574.

Pan, X., F. Chen, T. Wu, H. Tang dan Z. Zhao. 2009. The acid, bile tolerance and antimicrobial property of Lactobacillus acidophilus NIT. Journal Food Control. 20(6): 598-602.

Poedjiadi, A. dan T. Suprayanti. 2006. Dasardasar Biokimia. UI Press, Jakarta.

Poelongan, M., I. Chairul, S. Komala, Salmah dan M.N. Susan. 2006. Aktivitas antimikroba dan fitokimia dari beberapa tanaman obat. Dalam Seminar Nasional Teknologi Peternakan dan Veteriner. Balai Penelitian Veteriner, Jakarta. p 974978.

Rahayu, E.S., A.K. Wardani dan S. Margino. 2004. Skrining bakteri asam laktat penghasil bakteriosin dari daging dan produk olahannya. Jurnal Agritech. 24(2): 74-81.

Saenz, Y., R. Bezares, L. Novaro, L. Diez, S. Somalo, M. Zarazaga, F.R. Larrea and C. Torres. 2009. Genetic Diversity of pln Locus Among Oenological Lactobacillus plantarum Strains. International Journal Food Microbial. 134(3): 176-183.

Sankar, N. Ravi, V.D. Priyanka and P.S. Reddy. 2012. Purification and characterization of bacteriocin produced by Lactobacillus plantarum 
isolated from cow milk. International Journal of Microbiological Research. 3(2):133-137.

Sari, R., L. Desliandri dan P. Apridamayanti. 2016. Skrining aktivitas antibakteri bakteriosin dari minuman ce hun tiau. Jurnal Pharmaceutical Sciences and Research. 3(2): 88-96.

Situmeang, S.F.M., Musthari dan S. Riadi. 2017. Isolasi dan uji aktivitas antimikroba bakteri asam laktat dari yoghurt dalam menghambat pertumbuhan bakteri Escherichia coli dan Salmonella typhi. Jurnal Biosain. 3(3): 144-152.

Smid, E.J. dan L.G.M. Gorris .2007. Natural Antimicrobial for food Preservation. M. S. Rahman (Eds). Handbook of Food Preservation. CRC Press, New York.

Suwayvia, N. 2017. Produksi Bakteriosin Asal Lactobacillus plantarum FNCC 0020 Sebagai Antimikroba dan Stabilitasnya pada Variasi Suhu Pemanasan, Suhu Penyimpanan dan pH. Skripsi. Fakultas Sains dan Teknologi Universitas Islam Negeri Maulana Malik Ibrahim Malang, Malang.

Syahniar, T.M. 2009. Produksi dan Karakterisasi Bakteriosin asal Lactobacillus plantarum 1A5 serta Aktivitas Antimikrobanya terhadap Bakteri Patogen. Skripsi. Fakultas Peternakan, IPB, Bogor.

Urnemi, S. Syukur, E. Purwati, S. Ibrahim dan Jasmari. 2011. Potensi bakteri asam laktat dalam menghasilkan bateriosin sebagi antimikroba dan pengukuran berat molekulnya dengan SDS-PAGE dari isolat fermentasi kakao. Jurnal Riset Kimia. 4(2): 94100.
Usmiati, S. dan T. Marwati. 2007. Seleksi dan optimasi proses produksi bakteriosin dari Lactobacillus sp. Jurnal Pascapanen. 4(1): 27-37.

Vaughn. 1982. Lactic acid fermentation of cabbage, cucumber, olives and other product. In Prescott and Dunns Industrial Microbiology 4 edition. AVI Publishing Co, Texas.

Villani, F., M. Aponte, G. Blaiotta, G. Mauriello, O. Pepe and G. Moschetti. 2001. Detection and characterization of a bacteriocin, garviecin L1-5, produced by Lactococcus garvieae from raw cow's Milk. Journal Applied Microbiol. 90(3): 430-439.

Vuyst, L.D. and E.J. Vandamme. 1994. Antimicrobial Potential of Lactic Acid Bacteria. In Bacteriocins of Lactic Acid Bacteria: Microbiology, Genetic and Application. L.D. Vuyst dan E.J. Vandamme (eds.). Blackie Academic \& Professional, London. p 91-142.

Vuyst, L.D. and F. Leroy. 2007. Bacteriocins from lactic acid bacteria: production, purification, and food applications. Journal of Molecular Microbiology and Biotechnology. 13(4): 194-199.

Wasis, N.O., N.S. Antara dan I.B.W. Gunam. 2019. Studi viabilitas isolat bakteri asam laktat yang diisolasi dari asinan rebung bambu tabah terhadap $\mathrm{pH}$ rendah dan garam empedu. Jurnal Rekayasa dan Manajemen Agroindustri. 7(1): 1-10. 